\title{
Mental Impact
}

\begin{abstract}
In this chapter, we describe our encounters with targeted surveillance and intimidation, betrayal, and being confronted with hard stories of suffering, torture, and brutal murder. We consider the feelings of stress, fear, and paranoia that may result from operating in a repressive environment and what we need to do, individually and institutionally, to mitigate and manage the harmful mental impact of fieldwork. We then turn to how pressure to get results, and a sense of shame and career worries associated with not getting them, can compound negative impact of fieldwork. Finally though, we also record the positive effects of fieldwork on our psyche and worldview. We conclude with the importance of making it possible to talk about mental impact, before, during, and after fieldwork.
\end{abstract}

Keywords Authoritarianism • Field research • Surveillance $\bullet$ Stress • Trauma • Career pressure

In this chapter, we will discuss a topic that we believe receives too little attention: the mental impact that being in the authoritarian field has on us. As in earlier chapters, we focus on the specificities of the authoritarian field while recognizing that some of our observations may well apply to other kinds of 'difficult' contexts too. We all experience fieldwork as times of excitement as well as stress. Being away from our home life, in the presence of some risk, and having to process things very quickly, is tiring but

(C) The Author(s) 2018

M. Glasius et al., Research, Ethics and Risk in the Authoritarian Field, https://doi.org/10.1007/978-3-319-68966-1_5 
at the same time gives us a lot of energy, because we get a lot of input. What is common to all kinds of fieldwork, and stressful in itself, is that we try to gather as much information and speak to as many relevant people as possible, always in a limited time. We often worry about whether we have done enough, and have the sense that we can always do more. For firsttime researchers, an especially big question looms: will people talk to me at all?

Also common to all fieldwork far away from home, is our need to adjust to a context very different to our own. This extends to seemingly mundane problems like pollution and traffic, that can nonetheless have a considerable impact on our state of mind. Then there is the social and cultural adjustment. Even our China researcher, who is ostensibly visiting 'home', finds herself marveling at the hierarchy in the workplace and in the family, the way people treat each other in the street, and getting irritated by value differences even in conversations with friends. Our Iran researcher finds many of his close contacts depressed by the political and economic obstacles they face, and in turn he finds their inability to realize their potential depressing.

As researchers in authoritarian contexts, we probably face more refusals and less openness than other researchers. This can come in the form of avoiding an interview, as described in the last chapter. Even when we do get the interview, especially with officials, we are always playing a game, where we do not cross the red lines, but skirt around the edges, trying to draw out as much information as we can. Our obstacles can also relate to documents that we know exist, but that our respondents do not want to share with us, perhaps because their bosses will not give permission, or more generally because it is better in authoritarian bureaucracies not to take such initiatives. As a result, we can feel frustrated, knowing the information is there but we cannot get it (see Barros 2016, 964-965, on bureaucratic secrecy in authoritarian contexts). And while, as we have stressed before, authoritarian contexts are not unsafe for foreign researchers most of the time, they are marked by persistent uncertainty. We never know precisely what the regime knows and thinks of us and under what circumstances it might abruptly conclude that what we are doing is causing them a problem.

Below, we describe our encounters with targeted surveillance and intimidation, and the feelings of stress, fear, and paranoia that we have experienced as a result of operating in a repressive environment. We discuss the impact of either direct betrayal by, or a sense of disenchantment 
with, people we had cordial relations with in the field, and the impact of being confronted with hard stories of suffering, torture, and brutal murder, in the field or afterward. We consider the underdeveloped topic of what we need to do, individually and institutionally, to mitigate and manage the consequences of harmful mental impact of fieldwork: making mental impact a subject that can be discussed and made subject to a range of coping strategies; reflecting on the effects of stressful incidents and hard stories on validity and bias of our research; reconsidering after such events what fields, what subjects, and research questions we still can and want to investigate; and the physical impact of mental stress. We then turn to a broader issue in academia that can compound negative mental impact and complicate the usual mitigation strategies: the pressure to get results and the sense of shame and career worries associated with not getting them. Finally though, we also record the positive effects of fieldwork on our psyche and worldview. We conclude by emphasizing how helpful we have found sharing our fears and dilemmas. By doing so we hope to counter the academic predilection for focusing on achievements over discussing doubts and difficulties.

\section{Targeted Surveillance}

Since the Snowden revelations, the idea that our transactions, communications, and even our documents may be monitored and analyzed by unseen entities without our knowledge or permission has turned from an outlandish conspiracy theory into an open possibility for most Internet users worldwide. Interestingly, we find that this seems to be making us rather stoical about the possibility of being under electronic surveillance from the authoritarian regimes we investigate. Since our overall policy is to be open about the work we do, we do not encrypt or hide away our documents, other than transcripts or respondent contact details, as described in the last chapter. Drafts of this book, for instance, have been edited and saved on various servers and clouds.

Our China and Kazakhstan researchers have never personally noticed signs of surveillance. They are cautious about contact with vulnerable respondents online, but mostly the idea of surveillance remains rather abstract and does not affect them. The Kazakhstan researcher used to work in a formerly government-owned building that was commonly believed to be wired, but did not really care, nor did her coworkers. The China researcher has noted how quickly her Chinese acquaintances adapt, 
and develop language online that is mutually understood, but not picked up or blocked by automated censorship devices. She found that many of her interviewees happily contacted her via social media in the knowledge that there might be surveillance.

Our attitudes change when we get concrete indications that, rather than just being absorbed into general surveillance and censorship practices, we are specifically being targeted by security agents. Our Morocco researcher is certain that she was under electronic surveillance during one particular fieldwork period. Returning to her hotel after an interview, she opened her laptop and saw that her Google mail account had been accessed while she was out. She also received phishing e-mails that would appear to fit with what Moroccan activists and journalists have reported (Privacy International 2015). She has not had indications of electronic surveillance on subsequent field trips, but she is convinced that her phone is tapped when she is in Morocco and is careful about what she says on the phone. It took her time to come to terms with this. By repeating to herself that the people undertaking the surveillance were only doing their job, as she was doing hers, she regained her peace of mind. The electronic surveillance episode to her mind has validated her approach of taking handwritten notes rather than recording interviews (see ch.6).

Our Malaysia researcher does not have similarly definitive evidence, but both activists and ordinary Malaysians have told him that they assumed the authorities were reading his e-mail and WhatsApp messages during his field research. The activists he interviewed were fairly certain that they were being monitored: after they had agreed via WhatsApp to meet each other at a particular coffee house, special branch people would typically be seen at the coffee house at the appointed time. Initially our researcher was shocked to hear this and very cautious in his questioning. On reflection, however, he decided that if asked during an interview what he was doing, he would stick to our policy of openness and not lie but simply explain that he was conducting an interview. His respondents did not appear particularly intimidated, and for himself, he later thought, eviction was the worst thing that was likely to happen. One of the Mexico researcher's respondents similarly told him during an interview that phone conversations were tapped, and it was likely that security agents knew that the interview was taking place. As we will detail below, they had much more reason to be afraid than their Malaysian counterparts. Our Iran researcher similarly suspects that when 
he met journalists in their newspaper offices, these buildings were under surveillance, and notes may have been taken to document his visit. Giving in to this thought could make him feel somewhat paranoid from time to time, but he decided not to be deterred by a mere suspicion of surveillance.

In these cases, it remains ambiguous how pervasive the surveillance effort was, and also whether regime agents wanted us to know they were monitoring us, or tried to be subtle. While there may be exceptions, we should assume that in an authoritarian context, critical journalists and activists are likely to be under (online and/or offline) surveillance to some degree, and there is a good possibility that we as researchers may come under the radar if we contact them, even if we never notice it. None of this was ambiguous when our Morocco researcher was investigating human rights abuses committed against-real or supposed-Salafists. Soon after her meeting with relatives of Salafi prisoners (detailed below), she was conducting an interview in an otherwise empty coffee house, and two people came to sit at the next table, pretending to read a newspaper but clearly listening in to the interview. During the next two days, she was continually being followed. A man sat down next to her in a nearly empty train. She moved to another seat, but again she was followed. When she got out of the train, he was still there. When she arrived at the airport, the same person was in the queue behind her, but then magically appeared in front of her after security control. This was surveillance intended to intimidate, and it did.

For reasons detailed below, the Morocco researcher nevertheless returned to Morocco, but this time prepared a number of safety measures, making arrangements to meet friends at the airport, informing the Italian embassy of what she was doing, and asking for official permission to do the research. Faced again with intrusive surveillance, she met a friend at a coffee bar and, again with a security agent in a nearly empty café as audience, told her friend that she had no interest in the Salafi research; she was just doing it because she needed the money, her real interest was in women's rights. When for months her request for authorization remained 'in process', she acted according to her own stated intentions, and gave up the research on Salafists. She experienced some more surveillance, but as it became increasingly clear that she was no longer following this line of inquiry, the surveillance melted away. She had encountered a red line (see Chap.3) and has chosen not to cross it again. 


\section{Stress, Fear, and Paranoia}

Most of the time when we are doing fieldwork, we are not afraid, we feel comfortable in the environment in which we are staying. Indeed, it would be impossible to do our work, staying in the field for weeks and sometimes months, if it were otherwise. But we want to come out and say that sometimes, when doing research in the authoritarian field, we feel anxious, afraid, even a little paranoid.

For some of us, the most frightening incidents have been those where we were directly targeted, such as the intrusive surveillance experienced by our Morocco researcher, described above. Our Malaysia researcher was quite frightened after the incident, described in Chap. 2, in which plainclothes police had photographed his passport. It was at this same time he discovered that his e-mail was probably being read. Moreover, the incident occurred within weeks of the death of Giulio Regeni, and the Dutch embassy had helpfully told him that a Dutch person was sometimes arrested and held for weeks without the embassy being informed-possibly to deter him from attending the demonstration. He spent a sleepless night expecting a knock on the door, and for the next few days continually considered the possibility of being arrested. After a few days, when nothing happened, he recovered his calm and continued his fieldwork uneventfully.

Our Iran researcher has experienced a terrifying incident with a much longer tail. In Chap. 4, we described how he had been tricked by a former journalist turned informer into corroborating this man's fake arrest, so as to bolster his cover. A year later, the same man (whom our researcher still believed to be his friend) showed up at his apartment, admitting that he worked for the security services and claiming that these had become very suspicious of the researcher. The man, whom we shall call Ramin here, could help close the file, but he needed money. Ramin then announced that 'one of my colleagues will enter your apartment also and he will search your apartment, but I will protect you.' Indeed, a second man came, and our researcher really panicked. Ramin wanted 4000 or 5000 euro, while the second person started searching the researcher's wastepaper basket and computer, finding handwritten notes about the arrest of bloggers and some saved articles by an Iranian French scholar, about whom they proceeded to interrogate him, closing the curtains of the apartment. They tried to get him off-balance. 
He felt a mix of panic and amusement, because the situation was scary but also somewhat ridiculous, with both men behaving like movie script intelligence agents or interrogators. He remembers repeatedly thinking 'come on, now you are overdoing it' as the incident unfolded. Eventually, they allowed him to call someone, ostensibly to get the money. He called a friend, who could tell from his voice that he was very scared, and immediately called the French research institute with which he was affiliated. Eventually someone from the French embassy came to the apartment and took our researcher with him, to safety. Soon after, he left the country for a few weeks, in part for his safety, but especially also to calm down. In this case, it remains unclear whether the primary purpose of the plot was to steal money or to induce fear, but it certainly had that latter effect.

In overtly repressive contexts, we may also experience moments of fear that have nothing to do with us personally. Our Mexico researcher has been vividly aware during his field research of certain locations that have been the scene of horrific events. Coming to a shopping center for an interview, he experienced mental images of what had happened there a year earlier: a truck full of dead bodies had been dumped in the street. Another source of temporary bouts of fear or discomfort for him were the federal police at every street corner. Not only were they heavily armed, they are known to have been involved in various political murders.

As we have stressed in Chap. 2, instances of intimidation of foreign researchers are relatively rare. But they happen just often enough, in the broader context of what we know of the repressive side of the regime, to make us always a little apprehensive during fieldwork. As Malekzadeh $(2016,868)$ has related in the context of Iran, the likelihood was that he would not be in any danger, but he 'could not be certain why agents had checked up on me or where it would lead. The problem, of course, was the uncertainty. Regimes like the Islamic Republic excel in sowing doubt'. It is quite clear who is in power, but there is always a residual uncertainty about what we are allowed to do, and what can happen to us.

\section{Betrayal and Disenchantment}

The emotional response of our Iran researcher to the intrusion into his flat and subsequent extortion attempt was not just one of fear. He also felt a sense of betrayal. When he had first come to know Ramin, he had come to consider him not just as a respondent but also as a friend, who had helped 
him understand the political context of Iran and whom he trusted. When he sent out the press release about the man's supposed arrest, he had been concerned for Ramin's safety. When the intrusion occurred, he came to understand, from one moment to the next, that this was not his friend, this was someone doing him harm. He had difficulty believing that this was really true. But the sense of betrayal described here is not just personal betrayal, it has to be understood in its authoritarian context. As it happens, our Iran researcher grew up in East Germany and thought that his youth had taught him always to be suspicious. Instead, he had been too trustful and forgotten how ugly the intrusion of an authoritarian regime in personal relations can become.

Also characteristic of authoritarian circumstances is the lack of clarity, until this day, about the exact nature of the incident. Our researcher filed a complaint with the police, and it became clear that the police was not involved - they were furious and considered the incident as a criminal act. Nor does Ramin appear to have been working for the ministry of intelligence: an Iranian lawyer made some informal inquiries and found that there was no file on our researcher. Later it transpired that Ramin had been involved in the arrest of bloggers and journalists; in the following years, he became an editorial writer for the hardline conservative press. But it remains unclear whether, at the time of the incident, he had been connected to any of the various parallel intelligence agencies and whether the incident was just a brazen attempt at extortion, or at least in part a political warning.

Without being personally betrayed as our Iran researcher was, others also have the experience of seeing people whom they believed to be idealistic turn into regime apologists. Our Morocco researcher spent quite some time with journalists who used to criticize the regime but now work for pro-government media. She is careful not to judge them: these people were young when she met them and may at some point have decided in favor of having a family and a normal life. The price of being a regime critic can be very high, and we might make the same calculation in their position.

Our Kazakhstan researcher's experience with a rising government official over the last decade is slightly different: this man was never a democrat, but he had previously been a believer in 'changing things from the inside' as well as a warm personal contact. The more he progressed in his career, the more his attitude toward our researcher became distant and bureaucratic, culminating in a meeting where he put on display the perks 
of office, keeping her waiting for a long time, and then having her ushered in by an aide and served tea by a secretary. This was the same person who asked her to write a propaganda story for the Almaty Olympics bid (see Chap. 4). After her refusal, the relationship has cooled, and she would no longer ask him for contacts or other work-related favors.

\section{HARD STORIES}

Many of us have spoken to respondents who have been in prison and who were in some cases tortured or raped. Perhaps surprisingly, these stories do not always deeply affect us. It depends very much on the way the respondent tells the story. Our consistent experience, in Kazakhstan, Malaysia, and Morocco, is that when respondents themselves appear to have processed what has happened to them, as a thing of the past, it is not shocking or traumatic for us to hear their experiences, even if they concern objectively painful events. When they tell us things they have already spoken about many times, rather than personally opening their hearts and sharing their pain or fear with us, the stories more readily take on the form of depersonalized data.

Conversely, a story does not need to be particularly gruesome to shock us, if it challenges our preconceptions of how things work, and the reality is more harsh. This was the experience of our Kazakhstan researcher when hearing what happened to her contact Irina, the director of an NGO she had long known. The NGO dealt with multiple issues, some of which are considered sensitive, and had previously had some bureaucratic difficulties, but always worked hard to maintain a relationship with the authorities. The evening before traveling to West Kazakhstan for an NGO event, Irina was attacked outside her apartment and robbed of her big purse full of documents, money for grants, hard disks, and everything necessary for the event. According to Irina and her colleagues, the attacker clearly must have known what was in the purse. A witness in a car refused to call the police; he was probably implicated. The event in West Kazakhstan then ran into other difficulties, with permits being revoked, and local hotels and the university refusing to host the event, compounding the likelihood that the attack was political in nature. Despite the fact that Irina was not physically hurt, our researcher was quite shocked by the story. She had previously been conscious that targeted violence was characteristic even of the 'soft authoritarian' context of Kazakhstan and had read of physical violence used by the regime before, but this was the first instance where it happened 
to someone she personally knew, which was like a revelation of something that had always been there but hidden in the background.

When we see our respondents in pain or afraid, especially when we come upon hard stories unexpectedly, the impact on us is much greater. This was the experience, for instance, of our Morocco researcher, who spent an afternoon meeting the members of an association for the rights of Salafist prisoners. She sat in a room full of women, the daughters, wives, and mothers of these prisoners. Each woman in turn told her story, and it was just one atrocity after the other. One ended her story about her son with 'and they condemned him to the death penalty'. Another appeared to have become mentally deranged as the result of the killing of her younger child and husband, and possible psychological torture. Had she been working for an organization like Amnesty International, our researcher might have been prepared to hear these stories, and would have known what to do with them: write a report. But she was unprepared, and felt alone against the ugliest part of humankind. During the meeting, our researcher remained clinical, asking questions, taking notes. She could not open the door to empathy because it would have overwhelmed her. The traumatic impact of these stories was compounded by the intrusive surveillance, described above, that followed immediately afterward, and by the pressure to get results, which we discuss further on in this chapter. For a time, she could not stop thinking about the stories, the derangement of one woman, the lifeless voice of another. Hiking, eating well, and spending time on her own eventually helped her recover.

Stories that unsettle us do not always come from those directly affected by them. Our Mexico researcher was shaken by the account of a forensic journalist who investigates crime scenes, including political murders. She told a story of careful planning and tremendous professionalism in the implementation of deliberately gruesome murders, intended to send a message to others. He was told similar stories by other respondents as well. Just like our Morocco researcher, his initial response was to get on with his work, ask more questions, analyze the situation, without considering the horror of what he had been told, and how it affected him personally. In fact, it is difficult to start processing the mental impact while in the field, when there are too many other things going on. We oftentimes need the safety of home, and the distance in time and space, to evaluate and deal with the impact the field has on us. If coping in the field becomes too hard, then going home early should be the obvious solution. However, 
as we will discuss below, the pressure to get results, and the shame of an unsuccessful trip can get in the way of such a sensible course of action.

\section{The Field Stays with Us}

One might assume that, since we are field researchers, bad incidents or stories that emotionally affect us are things that we should be prepared for during fieldwork, and then we go home and relax. We know political life in the 'field' does not stop when we take our plane, and we typically stay in touch, but still, the physical distance typically also translates into some emotional distance. But not always.

One of the more upsetting experiences our China researcher has had to deal with, happened in the United Kingdom. She acted as translator for a group of visiting Chinese local government officials from a region whose main city is famous for its peacefulness, quality of life, and international flavor, a reputation she had found confirmed during fieldwork. In her private conversation with one of the officials, she asked about a group of villagers who had occupied the highway in that locality, in a land-related protest. The protest had attracted a lot of attention, but then suddenly, all went quiet. She asked the local official what happened to the villagers, and he made an emphatic face and said: 'we dealt with it'. She asked, 'what do you mean?', but she knew very well what he meant. Our researcher was in no personal danger whatsoever in this exchange and had not even known the villagers. Nonetheless, she was shocked and saddened to hear directly from an individual who had chillingly 'dealt with' the villagers' rightful protest, even in this reputedly harmonious place.

Much more personal was the experience of our Mexico researcher. One of his main contacts during fieldwork had been a young photographer, Ruben Espinosa. Espinosa gave him several other contacts and sometimes came along to these other interviews too. Our researcher had interviewed him several times and also met him socially. He had been aware from the very first meeting that Ruben Espinosa had been threatened and feared being killed. A few months after the fieldwork, while he was at a conference, our researcher got a text message from another contact, telling him that Espinosa had been killed. It transpired that he had fled from the province of Veracruz to Mexico City, where he and four flatmates had been tortured and murdered. While nothing has been proven, it is widely assumed that this was a political murder, connected to an unflattering photograph and article about the provincial governor (Watson 2015; 
Goldman 2015). Less than a year later, a second contact went missing and was later found shot. This was not a respondent, but an acquaintance from an earlier trip, from whose parents our researcher had rented an apartment during fieldwork. The circumstances of his death are less clear, but it was a violent death, and the motive may also have been political. Initially, our researcher responded by having intensive contact with Mexican friends, and by writing two online articles for a broader audience (Bartman 2015a, $2015 \mathrm{~b}$ ). This helped him feel that he was doing something to draw attention to the murder of journalists in Mexico. But it was not enough: he experienced trauma symptoms such as stress and insomnia and eventually sought counseling. This has taught him to approach traumatic events not just analytically, but to acknowledge the emotional impact: feelings of fear, anger, and guilt. He has also de-intensified his contact with people in the field, and does not contemplate going back to the same province in the near future. For the sake of optimal data-gathering, a repeat visit might have been desirable, but just as in the case of the research on Salafists in Morocco, it was deemed simply too risky to do so, even apart from the emotional strain.

\section{Attending to and Coping with Mental Impact}

The lesson from the experience described above is certainly not that everyone needs to seek counseling after authoritarian fieldwork, let alone before it. We should tread lightly, and not overburden first-time researchers with unnecessary expectations of getting traumatized. Most of us are not traumatized by the authoritarian field most of the time. Nonetheless, individually as well as collectively as an academic community, we should recognize that our fieldwork experiences can sometimes have a severe, perhaps even traumatic, emotional impact on us (see Loyle and Simoni 2017 for a more extensive plea for engagement with the possibility of trauma). This has not traditionally been a subject of academic attention, and the difficulty can be compounded by our sense that, compared to the suffering of some of our respondents, our own vicarious feelings are not worth mentioning. But we should attend to them, and we do not do our respondents a disservice by doing so.

NGO workers, whether they do human rights or humanitarian work, are trained in stress release and listening techniques, and typically debriefed after a stay in the field. We often go to the same places, and we also do difficult work. If stress release methods or debriefing works for them, we 
should at least consider as researchers whether it can help us too. How exactly we need to respond will be different for each person and each situation. For some, professional counseling is in order, for others, spiritual (self-)help is the best answer. At a minimum, we should talk to friends and colleagues about what has happened and its impact on us. Others too have found that 'maintaining meaningful contact with others (friends, family, professional networks) is one of the best ways to mitigate the potential impacts of trauma' (Loyle and Simoni 2017, referencing Dickson-Swift et al. 2008). We would argue that this is all the more important in authoritarian contexts, which are already liable to propel us in the direction of paranoia and mental isolation. This is borne out, for instance, by the experience of Begley, who investigated what was behind the apparent popular support for the RPF in Rwanda, and not only encountered constant surveillance but also had to worry, more than we have had to do, about the risk her interviews posed to respondents. She writes how ' $(t)$ hese fears added to the increasing feelings of frustration, constant mistrust, feelings of always being watched, and having no one who understood the situation to offer advice or support, essentially imprisoned me, leaving no secure way to communicate anything to anyone' (Begley 2013, 82; see also Malekzadeh 2016, 868). It appears to have been this sense of isolation as much as the fear itself that caused her to suffer from post-traumatic stress after fieldwork.

Apart from recognizing stress symptoms, and finding our own personal ways of addressing them, we should also consider how stressful incidents, hard stories or traumatic events affect our written work. We should reflect on the possible validity gain, but also the risk of bias or self-censorship, once we ourselves or people we know personally have suffered from forms of repression. The quality of our conversations with colleagues who rely on desk-based work stands to gain from such self-reflection. And we should reconsider, after stressful incidents, hard stories or traumatic events on what fields we are prepared to revisit; what topics we are, and are not, willing to explore; and what methods we want to employ, in future research.

Then there is physical impact. While our team had extensively prepared for the specificities of authoritarian fieldwork, and given some attention to potential mental impact, we had neglected to consider the combined physical impact of pollution, temperature changes, change of diet, and hard work. If we experience stressful incidents, hard stories or traumatic events as described above, our bodies take yet another hit from the 
psychosomatic effect of such occurrences. All but one of our team got sick during recent fieldwork trips, though some of us much worse than others. So here we have some very practical advice: do not go on fieldwork unless you are in top shape, and plan not just for political but also for medical emergencies, determine who you would turn to with simple or complex medical problems, and how you would go about getting home early if necessary. Lastly, we will consider mental impact in relation to another source of stress, which we discuss in our next section "Pressure to Get Results".

\section{Pressure to Get Results}

A subject that has had some attention, but not necessarily specifically in the context of authoritarian fieldwork, is the pressure, especially on earlycareer scholars, to get results and publish them. Unfortunately, this problem has primarily been framed in relation to the temptation to cut corners or commit scientific fraud. We have no knowledge, or even suspicions, of scholars of authoritarianism who responded to pressure to publish by simply making up results. But almost all of us have experienced mental stress at the thought of a failed fieldwork trip, coming home with insufficiently robust findings to publish as an article. We also know instances, in our own experience and that of others, where pressure to get results led to flawed decision-making in relation to risk. A final concern is scientific: not the temptation to invent empirical data but a tendency to prejudge conclusions, and to confirm our initial hunches rather than listen carefully and with openness to what the field is actually telling us.

The pressure to get results comes from three interrelated sources: from ourselves, through informal peer pressure from our colleagues, and from our institutional environments. Social scientists are typically self-starters; ours is a highly individualist profession that does not suit those who need constant external guidance and prodding to get to work. We are often our own hardest taskmasters. Especially during fieldwork periods, which are expensive in time and money, and hence precious, we are likely to feel particular pressure to get results. This may just make us a little overenthusiastic and reckless, which is how our Malaysia researcher interprets his brush with Malaysian plainclothes police, described in Chap. 2, with hindsight. But it may also turn into more fundamental self-doubt about what we are doing in the field, and what could be the consequences of 'no data'. Sxther, who did research on critical journalism in China, is a rare voice 
actually admitting — after the fact - that during her PhD fieldwork, there were '(d)ays wasted watching American DVDs, reading spy novels or in other profitless ways' and that these 'empty days made me doubt the entire project' and imagine 'that my stay would end up as a complete failure'. As she explains, these empty days are generally omitted from any description of fieldwork, 'which emphasizes the active approach taken by the fieldworker' (Sxther (2006), 54-55, 43).

The sense of self-doubt may be exacerbated in contacts with colleagues. In our experience, discussing failure and frustration in field research is largely taboo. When you meet other researchers in the field, they may show off a little about their contacts and all the information they have gathered. Nobody will say 'I don't get interviews at all, things are going badly'. At conferences too, the assumption is always that you have results to share, they are not safe spaces to discuss difficulty in getting results. And yet, for many reasons detailed in the previous chapters, to do with prioritizing our own safety, with shifting red lines, or with reluctant respondents, authoritarian field research can simply fail. At least one of us, our Iran researcher, has experienced a field trip that yielded negligible results: at that time, about that topic, respondents simply would not talk to him. Our Kazakhstan researcher has not had such a disappointing experience in Kazakhstan itself, but hit a brick wall when trying to approach Kazakhstani students, and study their organizations, in the United Kingdom. Less dramatically, managing fewer interviews than you had wanted or expected is actually a pretty common experience.

The most consequential pressure to get results is hierarchical and institutional. PhD researchers, research assistants, and post-docs may experience pressure from their supervisor or project leader. They are expected to come back from the field with results. In our project, the project leader has in some cases put on the table in advance the possibility that, despite trying their very best, a researcher might come back more or less emptyhanded because the 'field does not yield', but we do not think this is common practice. We believe that senior researchers in this field have a responsibility to create an environment in which the possibility of disappointing fieldwork can be openly discussed. But beyond a supervisor, there are the economic bottom lines of the broader institutional environment: job security and research funding simply depend on past results. At the time of writing, only one of us eight coauthors has a tenured position. For the others, failing fieldwork can have direct consequences on the job market. 
It is this brute material fact that explains why our Morocco researcher went back for a second attempt at doing research on Salafists despite having been both traumatized by the stories of victims' relatives and intimidated by the security forces. She needed money to live and finish her $\mathrm{PhD}$, as well as wanting to maintain professional relations with the senior researcher who led the project. After months of trying and failing, she finally gave up on the project. Today, with much more experience, a doctoral title and a lengthening string of publications, she feels she has more room for manoeuvre in selecting which topics to work on. A Russia researcher one of us heard speaking at a conference undertook an even greater risk to continue his research on ethno-religious profiling in the Northern Caucasus, in order to 'come back from my fieldwork and not be “ashamed” of my research results' (Ratelle 2013, 208). Taking advantage of his own muscular appearance and adding some details (growing a beard, carrying a backpack), he would go through security checkpoints and allow himself to be detained and sometimes roughed up, to be able to write about it. In this case, apart from some degree of bravado, the perceived need to 'come home with data' appears to have been what drove this young researcher, who now acknowledges suffering from post-traumatic stress disorder. These experiences chime with Loyle and Simoni's argument that graduate students and pretenure staff 'constitute a high-risk group when considering the impact of research-related trauma' $(2017,142)$, precisely because the impact of exposure to violence and suffering is compounded by the pressure to get results. We cannot, and probably do not want to, fundamentally challenge an academic system that rewards theory-building based on solid data. But we do have a responsibility as an academic community to teach young researchers that no data-gathering for the sake of a career is worth knowingly putting ourselves through extreme treatment.

\section{Positive Mental Impact}

Contrary to what this chapter may have appeared to suggest so far, the mental impact of authoritarian field research does not just come in the form of frustration, fear, trauma, or stress. It has positive impacts too. Malekzadeh describes authoritarian field research as restorative, by which he means 'restorative of "the local" even as it informs nonlocal audiences outside of the case' $(2016,873$, see also 862$)$. We agree, but also find it restorative in another sense: inspiring and uplifting. We find that speaking to many different kinds of people in the authoritarian field has made us 
question some of our prior assumptions and ideas. It has helped us come to the full realization that what we do is social science: the stuff we study is about human beings, with all their complexities. Conducting many interviews has also helped us to be good listeners, which we find valuable not just as researchers, but as people. Fieldwork, in sum, has made us more open-minded, humble, and thoughtful.

\section{Chapter Conclusion: Talk About It}

In this chapter, we have discussed a number of issues that are rarely discussed in authoritarianism research: physical impact, surveillance, fear, betrayal, hard stories, traumatization, and pressure to get results. We want to stress that some of the events we have described are relatively rare. Authoritarianism research is mostly uneventful, and not particularly gruesome. But bad things do happen, to us and our respondents, and there are no easy fixes for either avoiding or dealing with them. Our best advice is to do precisely what we have done in these pages: talk about it, before, during, and after fieldwork.

During fieldwork, it is important to invest in 'warm contacts'. This is valuable not only because of the introductions they can make for us, or their analytical help, but also for our own well-being. We already discussed in Chap. 4 that trust is both a very valuable and a fragile commodity in authoritarian contexts. For our own sakes too, without trusting people unconditionally or unnecessarily sharing sensitive information with them, it can be useful to confide our insecurities and hesitations with a few people with whom we feel an easy connection. Some of us have experienced that when we isolate ourselves, we start overthinking our situation and getting negative thoughts. Our Iranian researcher believes that he would have understood the position of his rogue friend better and earlier if he had been more willing to discuss the situation with Iranian friends. Our China researcher found that it helped to share her sadness over the chilling fate of the protesting villagers with her supervisor. Our Malaysia researcher recovered his confidence after the incident with plainclothes policemen by talking to locals about it. Our Kazakhstan researcher found her severe and mysterious health problems in the field easier to bear because she was looked after by a friend.

During and after fieldwork, it is also useful to talk to colleagues about our frustrations and doubts about our work. When our research results are suboptimal, we are easily inclined to think we did something wrong: that 
we were too naïve, too reckless, or conversely we were too cautious and too self-censoring, and we could have had better results if we had acted differently. Our academic culture is not such that we readily talk about problems in field research. But having tried it, we have found it really useful to share experiences. It makes us feel better, sometimes do our research better, and sometimes learn that we could probably not have done it better.

\section{REFERENCES}

Barros, R. (2016). On the Outside Looking In: Secrecy and the Study of Authoritarian Regimes. Social Science Quarterly, 97, 964-965. https://doi. org/10.1111/ssqu.12350.

Bartman, J. (2015a). Wederom Journalist Vermoord in Mexico. Stuk Rood Vlees, 8. Retrieved from http://stukroodvlees.nl/wederom-journalist-vermoord-inmexico/.

Bartman, J. (2015b). Mexico's Deadly Truths. OpenDemocracy, 25. Retrieved from https://www.opendemocracy.net/jos-bartman/mexico\%E2\%80\%99sdeadly-truths.

Begley, L. (2013). The RPF Control Everything! Fear and Rumour under Rwanda's Genocide Ideology Legislation. In S. Thomson, A. Ansoms, \& J. Murison (Eds.), Emotional and Ethical Challenges for Field Research in Africa: The Story Behind the Findings (pp. 70-84). London: Palgrave Macmillan.

Goldman, F. (2015). Who Killed Rubén Espinosa and Nadia Vera. New Yorker Magazine. Retrieved July 14, 2017, from http://www.newyorker.com/news/ news-desk/who-killed-ruben-espinosa-and-nadia-vera.

Loyle, C., \& Simoni, A. (2017). Researching Under Fire: Political Science and Researcher Trauma. PS: Political Science \& Politics, 50, 141-145. https://doi. org /10.1017/S1049096516002328.

Malekzadeh, S. (2016). Paranoia and Perspective, or How I Learned to Stop Worrying and Start Loving Research in the Islamic Republic of Iran. Social Science Quarterly, 97, 862-875. https://doi.org/10.1111/ssqu.12342.

Privacy International. (2015). Stories of Surveillances in Morocco. Retrieved July 15, 2017, from https://www.privacyinternational.org/node/551.

Ratelle, J. (2013). Radical Islam and the Chechen War Spillover: A Political Ethnographic Reassessment of the Upsurge of Violence in the North Caucasus Since 2009. Ph.D., University of Ottawa. Retrieved from https://ruor.uottawa.ca/bitstream/10393/23791/1/Ratelle_Jean-Fran\%C3\%A7ois_2013_ thesis.pdf. 
Sxther, E. (2006). Fieldwork as Coping and Learning. In M. Heimer \& S. Thøgersen (Eds.), Doing Fieldwork in China (pp. 42-58). Copenhagen: NIAS Press.

Watson, K. (2015). Impunity Feared in Mexico Photojournalist's Murder. $B B C$, 10 August. Retrieved July 14, 2017, from http://www.bbc.com/news/ world-latin-america-33846438.

Open Access This chapter is licensed under the terms of the Creative Commons Attribution 4.0 International License (http://creativecommons.org/licenses/ by $/ 4.0 /$ ), which permits use, sharing, adaptation, distribution and reproduction in any medium or format, as long as you give appropriate credit to the original author(s) and the source, provide a link to the Creative Commons license and indicate if changes were made.

The images or other third party material in this chapter are included in the chapter's Creative Commons license, unless indicated otherwise in a credit line to the material. If material is not included in the chapter's Creative Commons license and your intended use is not permitted by statutory regulation or exceeds the permitted use, you will need to obtain permission directly from the copyright holder.

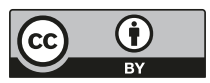

